\title{
A Proposal for Combatting Sexual Discrimination in the Military: Amendment of Title VII
}

\author{
Robin Rogers $\dagger$
}

Each branch of the military excludes women from combat positions. This Comment argues that the combat exclusion encourages sex-based discrimination in the military and should be reformed or eliminated. The author concludes that although the asserted justifications for the ban against women in combat are tenuous, an outright repeal of the combat exclusion is unlikely. She therefore suggests attacking the discrimination that emanates from the combat exclusion with an approach requiring concise articulation of the definition and underlying reasoning of the exclusion. For this purpose, the author proposes expanding Title VII to apply to the uniformed military. The author responds to arguments against authorizing the courts to address issues of discrimination in the uniformed military, concluding that the courts are an appropriate forum for the redress of these issues.

\section{INTRODUCTION}

Reports regarding the recent invasion of Panama brought the increasing importance of woinen in the military to the public's attention ${ }^{1}$ and forced many Americans to examine for the first time the often unacknowledged and increasingly ambiguous rules confining military women. Much has changed in the twenty-odd years since Congress repealed the two-percent ceiling on the number of women allowed in each branch of the armed services. ${ }^{2}$ Women now constitute more than ten percent of the armed services ${ }^{3}$ and occupy vital military positions previously closed to thein. ${ }^{4}$ Significant as these changes are, however, much within the mili-

$\dagger$ B.A. 1986, University of California, Santa Barbara; J.D. candidate 1990, Boalt Hall School of Law, University of California, Berkeley.

1. See, e.g., Wash. Post, April 22, 1990, at A15, col. 1; Chicago Tribune, Feb. 9, 1990, at 17, col. 1; N.Y. Times, Jan. 4, 1990, at Al, col. 5.

2. The Women's Arned Services Integration Act of 1948, Pub. L. No. 80-625, 62 Stat. 356 (1948), set the two-percent ceiling on the number of women pernitted to serve in each branch of the arned forces. In 1967, Congress passed legislation lifting the restrictions. Act of Nov. 8, 1967, Pub. L. No. 90-130, 81 Stat. 374 (1967).

3. Department of Defense, Military Women in the Department of Defense 45 (5th ed. 1987).

4. Aside from their participation in Panama, see N.Y. Times, Jan. 4, 1990, at Al, col. 5, women have played key roles in the Persian Gulf, Grenada, Lebanon, and the air strike in Libya. 
tary hierarchy reinains the saine. Despite the increasing inportance of women in our nation's military, inany military policies and procedures continue to reflect a inale-enclave mentality. Facially discriminatory policies, as well as more subtle forms of discrimination, continue to obstruct women's military careers.

Congress, for the most part, views the military as a unique realm governed by standards different froin those that govern the rest of American society. ${ }^{5}$ Consequently, Congress seems ambivalent toward the problem of sex discrimination in the military. Congressional policy reflects the belief that so long as the military fulfills its central task of defending the country, its values alone should determine military policies.

Congress' aunbivalence towards military policy makes sense only if the effects of discrimination within the military can be cordoned off froin the rest of society. Congress assumes that the larger coinmunity can achieve equity and equality while unequal treatment of the sexes continues in the military. But it is wrong-the negative effects of discriminatory military practices reverberate throughout society.

The military provides significant economic opportunities to its ineinbers. It employs more people than any single government agency or private company, ${ }^{6}$ and it is the "nation's largest single vocational training mstitution." It offers its inembers a way out of poverty and provides many lower class Americans with otherwise unavailable economic opportunities. $^{8}$ Military opportunities can be especially inportant to women, who as a class have historically been employed in the lower paying occupational strata. ${ }^{9}$ To the extent that discrionination denies women equal access to these opportumities, society as a wlole feels the effects.

The military provides its members with economic benefits that last long after they leave the military. The opportumities for education, training, and experience in the military can prepare servicemembers for future careers in the private sector. And retired military personnel receive ben-

Women in the Military: Hearings Before the Military Personnel and Compensation Subcomm. of the House Comm. on Armed Services, 100th Cong., 1st and 2d Sess. 28 (1987 and 1988) [hereinafter Women Personnel Hearings] (statement of Carolyn Becraft, Director, Women and the Military Project, Women's Equity Action League). Furthermore, in 1989 a woman was selected for the first time as first captain of the Corps of Cadets at West Point, the Academy's highest cadet honor. N.Y. Times, Aug. 9, 1989, at A1, col. 2.

5. Representative Holt expressed the view in her testimony against registering women for the draft, "You are talking about equity. I am talking about military." Registration of Women: Hearings on H.R. 6569 Before the Military Personnel Subcomm. of the House Comm. on Armed Services, 96th Cong., 2d Sess. 20 (1980) [hereinafter Registration Hearings].

6. M. BiNKIN \& S. BACH, WOMEN AND THE MiLITARY 31 (1977).

7. Id. at 35 .

8. Id. at 31-33.

9. See id. at 32 . 
efits that give them "a level of financial security that few men and even fewer women would be able to achieve in the civilian sector."10 For example, the Veterans Administration provides benefits and services such as hospitalization and medical care, guarantees of home loans, and life insurance. ${ }^{11}$ In addition, the Supreme Court has vahidated veterans' preference statutes that give veterans an advantage when seeking government jobs. ${ }^{12}$ Because of the disproportionately small number of women veterans, women, as a group, enjoy fewer of these financial rewards. But the availability of greater opportunities for women in the military would lead to a larger nuniber of female veterans, and could help women gam access to traditionally male-dominated civil service jobs.

The military also affects society im significant noneconomic ways. For example, it often has a socializing effect on its members. ${ }^{13}$ Military service mevitably influences the values and attitudes of military personnel, and ex-servicemembers take those values and attitudes with them into the civilian sector. The cumulative impact on American society can be substantial. At a minimum, the respect and responsibility women receive within the military affects the treatment of civilian women by exservicemembers.

In a larger perspective, the prevalence of sex-based roles in the military propagates discrimination throughout society. As the Supreme Court has recognized, the imposition of stereotypical sex roles can harm individuals, even when the categories are apparently benign. In Frontiero v. Richardson, ${ }^{14}$ the Court rejected the concept that "[m]an is, or should be, woman's protector and defender"15 as an example of "romantic paternalism' which, im practical effect, put women not on a pedestal, but

10. Id. at 34 .

11. SuRvey of Female Veterans: Office of Info., Mgmt. \& Statistics, Veterans AdMin., A Study of the Needs, ATtitudes aNd Experiences of WOMEN Veterans 162 (1985) [hereinafter WOMEN VETERANS].

12. Personnel Adm'r of Mass. v. Feeney, 442 U.S. 256, $261-62$ (1979). In Feeney, the Court upheld a Massachusetts veterans' preference statute that permitted consideration of qualified veterans ahead of all other applicants for classified state civil service positions. The plaintiff, who received higher scores than the veterans in several job placement examinations but still failed to get a job, argued that the statute discriminated against women. The Court acknowledged the statute's discriminatory impact but found that it lacked the requisite discriminatory intent to be held unconstitutional. Id. at $277,281$.

13. One commentator analogized the influential role of the military in socializing increasing numbers of young recruits to the role "once dominated by the family, the church, the school, and the civilian work setting." Carr, Education in the Military: A Look into the Future, in The Changing WORLD OF THE AMERICAN MiLITARY 416 (F. Margiotta ed. 1978).

14. 411 U.S. 677 (1972).

15. Id. at 684 (quoting Bradwell v. State, 16 Wall. 130, 141 (1873) (Bradley, J., concurring)) (striking down as unconstitutional a statute requiring uniformed servicewoinen, but not servicennen, to prove that their spouses are financially dependent on them before they can clain certain housing and medical benefits). 
in a cage."16 Tacit approval of discriminatory military policies gives credence to outdated notions of the proper roles for men and women, ${ }^{17}$ thereby limiting women's opportunities for personal achievement.

For many Americans, the concepts of citizenship and military service are integrally related. ${ }^{18}$ Defending one's country holds symbolic importance as a "unique pohitical responsibility."19 To the extent that women are barred from sharing fully in this patriotic responsibility, they are likely to be perceived as second-class citizens.

Furthermore, women's current and potential roles in the military may shape their political ideas and choices. ${ }^{20}$ Gender-based military distinctions affect women's sense of commitment and responsibility toward the state. Thus, the degree to which women are involved in the military helps to determine their stake in the formulation of national security policy. As one commentator has noted, "That stake, analogous to the stake a working woman has in the economic systein as opposed to the stake of a dependent wife, has the possibility of creating more informed and more intense involvement by women in matters of security, defence, war and peace."21 Sexual discrimination in the military burdens society as a whole. The problem deserves careful thought and analysis, rather than ambivalence.

This Comment discusses the problem of sexual discrimination in the military, identifying the combat exclusion as the root of the problem. Part I analyzes the combat exclusion, concluding that the arbitrary and inconsistent definition of combat results from the lack of a coherent and factually supported justification for the exclusion. Part II discusses how the combat exclusion itself harms women and how the military uses the coinbat exclusion to rationalize furtlier discriminatory practices. Part III evaluates the possibility of either eliminating the combat exclusion or using current intramilitary remedies to reduce its discrininatory effects. It concludes that neither is a viable solution. Part IV proposes that Congress amend Title VII to apply to the military, thereby requiring the mili-

16. Id.

17. See Stanton v. Stanton, 421 U.S. 7, 14-15 (1974).

18. See, e.g., The "Equal Rights" Amendment: Hearings Before the Subcomm. on Constitutional Amendments of the Senate Comm. on the Judiciary on S.J. Res. 61, 91st Cong., 2d Sess. 75 (1970) [hereinafter ERA Hearings] (statement of Jean Witter, Chairperson, Equal Rights Amendment Committee, National Organization for Women).

19. Goodman, Women, War, and Equality: An Examination of Sex Discrimination in the Military, 5 WOMEN's RTS. L. REP. 243, 246 (1979).

20. For example, observers note that vulnerability to the draft not only affects an individual's views on the country's foreign policy, but also affects how that person can express that view. Presumably, only a potential draftee can become a conscientious objector. See, e.g., id. at 248.

21. Stiehm, The Effect of Myths about Military Women on the Waging of War, in WOMEN AND THE MiLitaRy SySTEM 104 (E. Isaksson ed. 1988). 
tary to articulate a sound justification for any differential treatment of women.

\section{I}

The Combat Exclusion: Its Definitions and JUSTIFICATIONS

A discussion of sex-based discrimination in the military inevitably should begin with an examination of the combat exclusion-the restriction on positions open to women in the military. Much of the discrimination against military women stems, in one way or another, from this exclusion.

The definition of combat-and thus the classifications of specific positions as "combat" or "noncombat"- has varied dramatically during the last few decades. The definition's unsettled status appears to result from the absence of a coherent justification underlying the combat exclusion.

\section{A. Defining the Combat Exclusion}

Women may not hold combat positions in the Navy, the Air Force, or the Army. Congress imposed the exclusion for the $\mathrm{Navy}^{22}$ and the Air Force. ${ }^{23}$ Internal military policy established the Army's version of the exclusion. ${ }^{24}$ Decisionmakers within each service, however, ultimately

22. 10 U.S.C. $\S 6015$ (1988). Until 1978, the Navy's combat exclusion remained essentially in its original 1948 form, stating that woinen "shall not be assigned to duty in aircraft while such aircraft are engaged in combat missions nor shall they be assigned to duty on vessels of the Navy except hospital ships and naval transports." Pub. L. No. 80-625 $\$ 210,62$ Stat. 368 (1948). In 1978, a federal district court found the exclusion, which effectively banned women from all naval ship positions, to be unconstitutionally overbroad. Owens v. Brown, 455 F. Supp 291, 309 (D.D.C. 1978). The statute was therefore replaced with the version that currently states that "woinen inay. not be assigned to duty on vessels or in aircraft that are engaged in combat missions nor may they be assigned to other than teinporary duty on vessels of the Navy except hospital ships, transports, and vessels of a similar classification not expected to be assigned combat missions." 10 U.S.C. $\S 6015$ (1988).

23. 10 U.S.C. $\$ 8549$ (1988). Section 8549 states that "[f]emale members of the Air Force, except those designated under section 8067 of this title, or appointed with a view to designation under that section, may not be assigned to duty in aircraft engaged in combat unissions." The only revision of the Air Force combat exclusion since its enactment in 1948 has been the insertion of the noted exception in section 8067, pertaining to the appointınent of officers who serve in professional functions. 10 U.S.C. $\$ 8067$ (1988). Since the original exclusion applied only to women appointed under Title III of the Women's Armed Services Integration Act of 1948, Pub. L. No. 80-625 $\S 307(a), 62$ Stat. 373 (1948), it did not implicate the professional oceupations listed in section 8067.

24. Under 10 U.S.C. $\S 3012$ (e) (1988), the Secretary of the Army may "assign, detail, and prescribe" duties of Army members. The Seeretary of the Army has stated that woinen will be excluded only froin those positions involving the highest probability of "direct combat" with enemy forces. Women Personnel Hearings, supra note 4, at 144. The probability of direct combat for a particular position is determined by evaluating its unit's "tactical doctrine," location on the battlefield, and "Inission." Id. For the Army's definition of direct combat, see infra text accoinpanying note 30 . 
define combat. All military positions are classified as either combat or noncombat. Consequently, each service develops its own varied and often convoluted policies. As a result, the precise contours of the combat exclusion remain ambiguous and uncertam.

Although the combat exclusion was first codified in $1948,{ }^{25}$ a formal definition of combat was not articulated until three decades later. ${ }^{26}$ Since that time, the services liave developed their own respective policies interpreting the combat exclusion. The Navy bars women from participating in any "combat missions," defined to include any "mission of an individual unit, ship or aircraft that individually, or collectively as a naval task organization, has as one of its primary objectives to seek out, reconnoiter, and engage the enemy."27 Under a slightly different standard, the Air Force precludes assignment of women to "[a]ircraft whose principal mission involves aerial combat," 28 "[d]uties or units where there is a probability of exposure to liostile fire and substantial risk of capture," and "[i]nstructor or staff positions where training or experience in con1bat aircraft is a prerequisite." ${ }^{29}$ Finally, the Army uses yet another standard in determining combat exclusion restrictions. It bars wonen fron1 positions with a high probability of "direct combat." The Army defines direct conibat as:

engaging an enemy with individual or crew-served weapons while being exposed to direct enemy fire, a high probability of direct physical contact with the eneiny, and a substantial risk of capture. Direct combat takes place while closing with the eneiny by fire, maneuver, or shock effect in order to destroy or capture, or while repelling assault by fire, close combat, or counterattack. ${ }^{30}$

These service definitions of conbat focus on likelihood of violent

25. See supra notes $22 \& 23$ :

26. In 1978, in response to growing pressure to address concerns regarding women's roles in the military, Congress requested the Department of Defense to articulate a standard definition of combat. The Departinent of Defense responded that the term combat should be defined as "engaging an eneiny or being engaged by an enemy in armed conflict," but that such a definition did not provide a "useful basis" for discussion of women's service opportunities, since both inen and woinen had historically participated in the activities commonly included under the term. Department of Defense Authorization for Appropriations for Fiscal Year 1979: Hearings on H.R. 10929 and H.R. 7431 Before the House Comm. on Armed Services, 95th Cong., 2d Sess. 1190 (1978) [hereinafter Appropriations Hearings] (letter from Deputy Secretary of Defense C.W. Duncan, Jr. to House Speaker Thomas O'Neil (Feb. 14, 1979)). The Departinent of Defense noted that the various services used different definitions of "close combat" or "combat missions" to describe the categories of occupations from which women were actually excluded. $1 d$. at 1191. For the services' current definitions of these terms, see infra notes 27-30 and accompanying text.

27. Women Personnel Hearings, supra note 4, at 190.

28. Id. at 147. The Air Force defines "Aerial combat" as: "(1) Delivery of munitions or other destructive material against an enemy, or (2) Aerial activity over hostile territory where enemy fire is expected and where risk of capture is substantial." Id.

29. Id.

30. Id. at 144 . 
contact with the enemy. ${ }^{31}$ In practice, however, not all of the restricted military occupations are necessarily consistent with that focus. For example, the Army has at times classified such occupations as "plumber," "interior electrician," and "concrete and asphalt equipment operator" as combat positions. ${ }^{32}$ The defimition of combat has remained vague enough to allow the services to revise their hists of excluded positions, expandimg or contracting women's service opportunities as they do so. ${ }^{33}$

\section{B. Justifications for the Combat Exclusion.}

Before one can define coinbat for the purpose of implementing the exclusion one must first understand the justifications for the underlying policy. Why exclude women from combat? The central justification asserted is imilitary necessity. According to this view, physical, psychological, and social differences distimguish men from women. In essence, female combatants would weaken our nation's military capabilities. The fallacies of these justifications suggest, however, that the combat exclusion is primarily the product of emotional and instinctive responses predicated on outdated conceptions of the nature of war and the abihties of women. In hight of the lack of sound, logical justifications for the combat exclusion, it is not surprising that the classifications of military combat positions are so ambiguous.

31. See Women Personnel Hearings, supra note 4, at 69 (statement of Martin Ferber, Senior Associate Director, National Security and International Affairs Division, U.S.G.A.O.) ("The common theme in the application of the combat exclusion provision seems to be an effort to preclude women from the most frequent or severe exposure to the risks of war.").

32. OfFice of the Deputy Chief of StafF For Personnel, Department of the ARMy, WOMEN IN THE ARMY POLICY REview 4-18 (1982) [heremafter WITA].

33. In Hill v. Berkman, 635 F. Supp. 1228 (E.D.N.Y. 1986), the plaintiff brought a Title VII claim against the Army after learning that the Nuclear Biological and Chemical Specialist position, which she had intended to fill, had becn closed to women. The NBC Specialist was ainong several occupations which the Army closed as combat related, and then later reopened to women. Id. at 1232. (For discussion of Hill's unsuccessful Title VII claim against the Army, see infra notes 105 and 120.) In 1981, when the Army instituted its present policy of evaluating occupations by direct combat risk, it closed an additional 23 positions (beyond the 38 previously restricted) to women. WITA, supra note 32, at 4-17 to -18. In response to criticism, however, the Army restudied the positions and determined that 13 of the 23 specialties should be reopened to women. Yarbrough, The Feminist Mistake, 33 PoL'Y REv. 48, $49-50$ (1985); see also Women Personnel Hearings, supra note 4, at 72 (statement of Martin Ferber, Senior Associate Director, National Security and International Affairs Division, U.S.G.A.O.) (describing the 1978 Army position coding policy and subsequent change). In recent years, both the Navy and Air Force have aunounced plans to institute new classifications of combat-restricted positions. See, eg., Women Personnel Hearings, supra note 4, at 191-92 (statement of Vice Admiral L.A. Edney, U.S. Navy Deputy Chief of Naval Operations) (rcclassification of certain Naval combat positions), Los Angeles Times, Feb. 3, 1988, Part 1, at 10, col. 3 (removal of restrictions on certain Air Force positions previously classified as combat positions). 


\section{Physical Differences}

The most tenuous justification advanced for limiting women's roles in the military is that women's "lesser physical capabilities" 34 make them poor soldiers. That the average woman is smaller and weaker than the average male says httle about an individual woman's potential performance in military combat. When given proper training and the opportunity to prove themselves, military women demonstrated the required physical capabilities. ${ }^{35}$ In addition, "in most close combat a gun is the great equahzer"36 of plyysical disparities. Finally, since mucl of modern "combat" takes place with long-range weapons, computers, and electronic technology, technical expertise lias become more important than pliysical prowess. ${ }^{37}$ In fact, physical strength ranks low among the range of attributes needed by the modern combatant.

Furthermore, even if most women lack the physical strengtlı or endurance necessary for certain combat tasks, the military sliould not exclude all women from all combat positions. Ratlier, where suclı a qualification is needed, both male and female applicants should have the opportunity to demonstrate the requisite pliysical capability. ${ }^{38}$ In certain occupations, women's unique physical characteristics miglit be an asset. For example, a small and agile soldier may be better able to nianeuver within small spaces or velicles-a useful capability in certain front-line positions. ${ }^{39}$

More importantly, the positions designated as "combat" and tlus closed to woinen, are not necessarily the most physically denianding military jobs. Instead, criteria sucl as field placentent and unit nuission, wholly unrelated to physical strength, determine the classification. ${ }^{40}$ Thus, many coinbat positions may require no greater strengtlı or endurance than do occupations that wonien presently hold. Consequently the

34. Tuten, The Argument Against Female Combatants, in Female Soldiers-Combatants OR Noncombatants? 248 (N.L. Goldman ed. 1982).

35. For example, Major General Jeanne Holm describes the success enjoyed by the first women in the Air Force to undertake pilot training alongside male trainees. J. HOLM, WOMEN IN THE MilitaRy 320-22 (1982).

36. Registration Hearings, supra note 5, at 85 (written statement of Judy Goldsmith, Vice President-Executive, National Organization for Women).

37. See generally B. Blechman, U.S. Security in THE Twenty-First Century 8-23 (1987) (describing current and future military reliance on technology).

38. This requirement of individualized consideration, rather than reliance on the average characteristics of a class, is a hallmark of Title VII doctrine. See, e.g., Los Angeles Dep't of Water \& Power v. Manhart, 435 U.S. 702, 708 (1978) (striking down a requirement that female employees make larger contributions to a pension fund because actuarial data shows that they live longer on the average than men).

39. See Registration Hearings, supra note 5 , at 85.

40. WITA, supra note 32 , at 4-13. 
"physical differences" argument cannot justify use of the current definition of combat to exclude women.

\section{Psychological Differences}

A second theory posits that psychological differences between the sexes justify restrictimg women's employment in the military. Adherents to this view assert that women are less combative than men and lack the aggressiveness essential to combat. ${ }^{41}$

Generahzations regarding psychological characteristics of each sex cannot justify classifying all women in one behavioral group and ignoring individual traits. As im the case of physical capabilities, even if a specific attribute is more true of the average male or feinale, this fact alone is not deterininative of the capability of any individual male or female. Some woinen are undoubtedly inore capable and tenacious combatants than are soine men. Opening coinbat positions to these women would not mean operning them to all servicewomen, just as the present military systein does not presume that all male servicemembers are suited for frontline coinbat.

Moreover, one can question whether characteristics such as aggressiveness are biologically or socially determined. It may be that if women are encouraged-or even permitted-to assume roles requiring more "aggressive" characteristics, they may disprove traditional assumptions about women. Certainly soine women would gain enhanced aggressiveness through military training and indoctrination, particularly if that trait were critical in life-or-death situations.

\section{Sociological Arguments}

Other justifications for the combat exclusion suggest that the presence of women would have negative effects on male combatants' performance. One such argument suggests that "male bonding" plays an important role in combat group cohesion, and that placing women im coinbat units might have a detrimental effect on military cohesion and perforinance. ${ }^{42}$

The available empirical evidence does not support this sociological assertion. ${ }^{43}$ Unfortunately, the U.S. military has never conducted largescale tests on gender-integrated combat units operating on the front

41. Tuten, supra note 34 , at $254-55$.

42. Id. at 251-52.

43. Denmark has completed a four-year experiment in which women were assigned to naval combat duties. The study concluded that mixed-sex crews outperform single-sex units of either gender. As a result, the Danish Parliament has authorized the recruitment of women for all frontline naval assignments except submarine duty. Wash. Post, Sept. 21, 1987, at A1, col. 5. Almost all military specialties are open to women in Belgium, Holland, and Norway. Since the positions have only recently been opened to women, however, the effects of integration are as yet unclear. Women 
lines. ${ }^{44}$ The military has, however, undertaken several tests examining the effects of sexual integration in "combat support" units that service and maintam the combat effort. These experiments suggest that mixedsex units perform as well as or better than all-male umits in terms of military proficiency and group morale. ${ }^{45}$ Arguably, such experiments cannot simulate the sustamed stress and fear of actual combat situations. ${ }^{46}$ Still, the test results cast substantial doubt on the assumption that women's participation in combat units interferes with group cohesion.

Another unsupported assertion is that male servicemembers will take needless chances and make strategically incorrect decisions simply to protect female service cohorts. Even if many men are presently given to such protective impulses, it is likely that social change or military indoctrination will eventually modify such tendencies. Moreover, giving legal recognition to the sexually-discriminatory impulses of military personnel could threaten woinen's riglits outside the military if our society allows men's desire to "protect" women to limit women's opportunities. ${ }^{47}$

\section{Cultural Mores}

Settimg aside the need to balance principles of equity with military

Personnel Hearings, supra note 4, at 90 (statement of Dr. Sandra Stanley, Assistant Professor, Towson State University).

44. Representative Patricia Schroeder, however, has recently announced her intention to introduce legislation to enable Army women to undertake all military roles, including combat roles, in a four year "test unit." N.Y. Times, Jan. 4 1990, at A1, col. 5.

45. For a summary of studies on the effects of women in combat-support and combat-service support units, see U.S. AIR ForCE PERSONNEl Force CoMposition STUdY: AN ANALysis of The EfFects of Varying Male and Female Force Levels, ANNEX 5, at 2-21 to -23 [hereinafter USAF PERSONNEL STUDY]. One study concluded that the increased ratio of females in combat support units has had no significant effect on unit performance. Id. at 2-21. Furthermore, a survey of senior officers revealed that the presence of women in units had "a positive effect on group dynamics, particularly morale." Id. at 10-15.

46. See Tuten, supra note 34 , at 252.

47. In some ways, the Supreme Court's reasoning in Dothard v. Rawlinson, 433 U.S. 321 (1977), illustrates this danger. In Dothard, the Court upheld a male-only hiring policy for certain guard positions in Alabama's maximum security prisons, even though it stated that the bare argument that a particular job is too dangerous for women would not be an acceptable employment policy defense under Title VII. Id. at 335. The Court found that the justification behind the hiring policy went beyond the mere protection of women. The Court felt that women inust be excluded from the prison jobs to protect third parties, since women's presence in the violent atmosphere of the prisons would undermine security. Id. at 335-56. Justice Marshall's dissent, however, pointed out that "[t]he proper response to inevitable attacks on both female and male guards is not to limit the employment opportunities of law-abiding women who wish to contribute to their community, but to take swift and sure punitive action against the inmate offenders." Id. at 346. Similarly, in the conibat realn, women should not be summarily banned because of their very "womanhood." Instead, the goal should be to reduce the psychological, social, and political barriers to women's participation in the nilitary. 
imperatives, advocates of the combat exclusion cite a more fundamental, instinctive reason for barring woinen from the front lines. They argue simply that a civilized society does not send woinen into battle. The message is that we inust protect our daughters and wives froin the danger and horrors of combat. ${ }^{48}$

But these protectiomist ideals do not accord with the reality of warfare. Even though they cannot hold coinbat-classified positions, women play a significant role in our military and share the dangers and horror of combat.

Fewer and fewer military missions will entail face-to-face coinbat between adversaries. Instead, "combat" assignments will often consist of programming coinputerized or electronic equipment far froin the target or battleground. ${ }^{49}$ Moreover, front-line servicemembers are not the only ones at risk during warfare; the developinent of long-range weaponry has "enlarged the battlefield until it enconipasses all the territory of nations at war." 50

In fact, despite the combat exclusion, women have always been subjected to the violence and horror of war. Women serving in servicing and refueling units, ${ }^{51}$ and especially front-line inedical units, often face the same degree of danger and exposure to conibat as do officially designated combat troops. ${ }^{52}$ Moreover, the recent events in Panama underscore the difficulty in drawing sharp distnictions between the danger faced by des-

48. Legislative hcarings on the Equal Rights Amendment, the opening of the service academies to women, and the registration of women for the draft are replete with statements by military officials, legislators, and civilians citing the unthinkable vision of young women in combat as explanation enough for the combat exclusion. See, e.g., Registration Hearings, supra note 5, at 103 (statement of Kathleen Teague, representing Phyllis Schlafly, Coalition Against Drafting Women) ("American mothers and fathers have sent their sons off to battle in three wars. . . But American fathers and mothers are not willing for their daughters to be trcated the same way."); Hearings To Eliminate Discrimination Based on Sex With Respect to the Appointment and Admission of Persons to the Service Academies: Hearings on H.R. 9832 Before Subcomm. 2 of House Armed Services Comm., 93d Cong., 2d Sess. 147 (1974) [hereinafter Academy Hearings] (statement of Lieutenant General A.P. Clark, Superintendent, U.S. Air Force Academy) ("[T] he stresses that are involved in combat, that make demands on an individual, especially in a leadership position, are almost beyond description . .. and I don't think we should inject our women into that role if we don't have to.").

49. B. BleichmaN, supra note 37, at 12-13. Secretary of the Navy W. G. Claytor testified in the 1978 hearings on the amendment of the Naval combat exclusion that "[ $t$ ]here is no hand-to-hand combat in the Navy. . . . You don't board enemy ships with a cutlass in your teeth any more. This is all done by electronics and long-range missiles and that type of thing." Appropriations Hearings, supra note 26 , at 1204 .

50. Tuten, supra note 34 , at 240.

51. For example, although women entering the Army today are barred from joining forward combat battalions, they can join forward support battalions. Women Personnel Hearings, supra note 4, at 148 (Department of Defense Task Force Report on Women in the Military).

52. Appropriations Hearings, supra note 26, at 1190-91 (letter from Deputy Secretary of Defense C.W. Duncan, Jr.); see infra note 68; see also WoMEN VETERANS, supra note 11, at 21-22 (women veterans' reports of their combat experience). 
ignated combat and noncombat units. ${ }^{53}$ Clearly, regardless of whether our society acknowledges the reality, we cannot realistically protect servicewomen from the danger of combat in a war.

Nevertheless, the combat exclusion remains in effect. The exclusion persists despite the lack of a clear and factually supported justification for it, because it appeals to its supporters on an instimctive, emotional level. In practice, such a base of support makes the combat exclusion impervious to attack. One can challenge faulty factual assumptions, but changing attitudes and mstincts is often much more complex.

\section{II}

SeXual Discrimination In the Military: The Combat EXClusion as Primary Culprit

The combat exclusion affects women's military experiences in a number of ways. Most obviously, the exclusion bars women from entering certain military positions, thus closing off particular avenues of training and advancement. It remforces stereotypical beliefs and discrimmatory attitudes towards women in the military. And by showing that Congress will allow discriminatory policies in the military with little sound justification, the exclusion encourages the military to pursue other discriminatory practices.

Most importantly, by setting forth a system in which women cannot participate in the military's central nnission, the combat exclusion defines a world where women are presumed to be less valuable members of the military system. The combat exclusion thus makes it easier for the military to justify other discriminatory policies. Starting from the premise of the combat exclusion-that men and women are not equal-a myriad of discriminatory practices may flourish.

This underlying theme of inequality reinforces and validates certain attitudes toward woinen in the services. These attitudes may manifest themselves in more subtle forms of discrimination than officially sanctioned policies, but the deleterious effects on women are apparent.

\section{A. Direct Harms to Women}

The combat exclusion precludes women from occupying not only combat specialties but certain noncombat positions as well. In some situations, the military bars women from certain positions in order to reserve rotation positions for male members serving on combat-risk missions. ${ }^{54}$

53. At least one military police unit comprised of both men and women, commanded by a woman, was fired on and returned fire in the course of its operations in Panama. See N.Y. Times, Jan. 8, 1990, at A9, col. 5.

54. See, e.g., Appropriations Hearings, supra note 26, at 1191 (letter from Deputy Secretary of Defense C.W. Duncan, Jr.) (Naval rotation restrictions). 
Also, female servicemembers cannot specialize in areas in which the number or distribution of closed positions impedes career advancement in that specialty area. ${ }^{55}$ Finally, women are also barred from some noncombat positions that are mvolved in the same conflict areas as combat units. $^{56}$

Beyond the job categories that it exphicitly closes to women, the combat exclusion also affects women's service opportumities in a variety of other ways. In the past, it served as a justification for prohibiting women from entering the service academies. ${ }^{57}$ Although women can now attend the service academies, ${ }^{58}$ the combat exclusion continues to hamper their opportumities for training and advancement to higher paying occupations in the military. As the Supreme Court acknowledged in Schlesinger v. Ballard, ${ }^{59}$ the combat exclusion restricts women's abilities to gain the experience necessary for promotion withm the military. ${ }^{60}$ Because military leadership training is most frequently acquired in combat-type positions, the combat exclusion places women wishing to obtain qualification for high-level positions at a disadvantage.

The combat exclusion also restricts the number of women who can enter the military im the first place. For example, the Army permits a limited number of males without higli school diplomas to enlist once they have obtained a General Education Development certificate; the Army prohibits women from doing the same. In Lewis v. United States Army, ${ }^{61}$ the plamtiff, a woman who had not graduated from high school but who had obtained a General Educational Development certificate and had earned some college credits, brought suit challenging the constitutionality of the Army's enlistment policy. A federal district court dismissed the claim, stating that because the combat exclusion results in fewer

55. Women Personnel Hearings, supra note 4, at 144-45 (Department of Defense Task Force Report on Women in the Military).

56. Id. at 157 (testimony of Dr. David Armor, Principal Deputy Assistant Secretary of Defense).

57. Academy Hearings, supra note 48, at 67-69 (testimony of Hon. Martin R. Hoffman, General Counsel, Department of Defense); id. at 89-90 (testimony of Hon. J. William Middendorf III, Secretary of the Navy); id. at 131-32 (testimony of Hon. John L. McLucas, Secretary of the Air Force); id. at 161-62 (testimony of Hon. Howard H. Callaway, Secretary of the Army).

58. Opponents of the aeademy restriction disagreed with each other as to the merits of the combat exclusion, but they agreed that the exclusion could not justify the academy restriction. Instead, they argued that the academy restriction unjustifiably prevented women from obtaining the necessary training and credentials for high level advancement within the military. Id. at 243 (testimony of Representative Donald M. Fraser). In 1975, this argument for equality finally prevailed, and the military opened the service academies to women. Dept. of Defense Appropriation Authorization Act, 1976, Pub. L. No. 94-106 § 803(a), 89 Stat. 531, 537 (codified as amended at 10 U.S.C. $\S 4342$ (1988)).

59. 419 U.S. 498 (1975).

60. Id. at 508 ("male and female line officers in the Navy are not similarly situated with respect to opportunities for professional service") (emphasis in original).

61. 697 F. Supp. 1385 (E.D. Pa. 1988). 
openings for woinen, the Army was justified in setting higher adinissions requirements for thein than for men. ${ }^{62}$ The court found that, because 1nen and women are not similarly situated in the military by virtue of the combat exclusion, military enlistinent standards favoring men are constitutional. ${ }^{63}$

\section{B. Indirect Harms}

Many of the discriminatory effects of the coinbat exclusion are readily apparent, since they provide clear-cut examples of unequal treatinent of the sexes. The combat exclusion also fosters discrimination in a less obvious manner by validating pohicies that differentiate the sexes, as well as attitudes that minimize women's contributions to the inilitary. The combat exclusion reinforces discriminatory attitudes within the military, nurturing discriminatory treatment extending beyond the exclusionary rules themselves.

The combat exclusion sets women apart from men, reinforcing the view that women do not belong in the military. ${ }^{64}$ Servicewomen are perceived as being out of place in the military-needing protection from the brutality of real warfare. ${ }^{65}$ Male servicemembers inay resent the encroachment imto the military system of these seeming incompetents, who appear to receive special treatment by being shielded froin the most dangerous military work. ${ }^{66}$

62. Id. at 1393. Similarly, supporters of rules imposing stricter requirements upon female applicants for Navy ROTC scholarships than upon male applicants have cited the combat exclusion to justify their position. See Kovac v. Middendorf, 424 F. Supp. 72 (D. Del. 1976). In Kovac, the plaintiff conceded that if the statutory combat exclusion for the Navy was constitutionally valid, differential treatment of the sexes under the scholarship program would be "rationally related to a governmental purpose." Id. at 77. The court rejected the plaintiff's challenge to the constitutionality of the combat exclusion itself, holding that in light of Congress' "broad power to provide for the national defense," Congress had a "compelling state interest" for the classification whieh was therefore constitutionally sound. Id. at 79.

63. Lewis, 697 F. Supp. at 1393. The court cited Rostker v. Goldberg, 453 U.S. 57 (1981), and Schlesinger v. Ballard, 419 U.S. 498 (1975), two cases in which the Supreme Court upheld military policies that treated men and women differently, rcasoning that men and women are not similarly situated because of the combat exclusion. For a discussion of lower courts' interpretations of Rostker, see infra note 81 .

64. As one commentator notes, "Each of the services in varying degrees . . . has attempted to restrict the numbers and career progression of military women. A message has been sent to military women, and men, that military women are not equal in the defense system." Women Personnel Hearings, supra note 4, at 28 (statement of Carolyn Becraft, Director, Women and the Military Project, Women's Equity Action League).

65. For servicewomen's descriptions of this problem, see N.Y. Times, Oct. 2, 1987, at A17, col. 1. See also J. Holm, supra note 35, at 311-12 (recounting resentment and harassment of women members in the service acadamies, where combat is perceived as the "primary purpose" of an academy education).

66. See Yarbrough, supra note 33, at 51. Sexual harassment, which may be one result of such hostility, appears to be widespread in the military. A study prepared for the Air Force suggested that sexual harassment is a problem for Air Force women, but also noted that increasing the 
A more subtle effect of the combat exclusion is that it makes women's military service mvisible. Although women cannot earn the distinction of taking part in the imstitution's "principal mission" of combat, ${ }^{67}$ they often share the same risks and responsibilities as those men sanctioned for front line combat duty. ${ }^{68}$ Classifying all women's positions as noncornbat obscures the bravery of military women. The description of women engaging only in noncombat tasks eclipses the image of the women who have served in combat situations, and been taken prisoners of war.

The perception that military women contribute less than their inale counterparts, a foreseeable consequence of a sanctioned exclusion, leads to tacit approval of other discriminatory policies and practices. For example, the services often bar single parents from enlisting, ${ }^{69}$ a policy witl a disproportionate impact on women. ${ }^{70}$ Whereas the courts generally strike down such policies in civilian contexts, ${ }^{71}$ their use by the

proportion of women in a given group decreases the probability of harassment. USAF PERSONNEL STUDY, supra note 45 , at $9-22$ to -23 .

67. WITA, supra note 32 , at 3.

68. Secretary of the Navy W.G. Claytor testified, in hearings on the opening of Naval ship duties to women, that the transport ships on which women have always served have been the "target ships" in combat. Appropriations Hearings, supra note 26, at 1201. More recently, the Department of Defense Task Force Report on Women in the Military noted its concern that "[w]omen are currently utilized in units or theaters of operatiou in which they will be exposed to substantial risk of hostile fire or capture. . . Examples include Army rear-of-brigade artillery and forward support battalions; Air Force ground launched cruise missile (GLCM) sites; airborne early warning and control systems; refueling tankers; and, Military Sealift Command ships that travel to and supply battle groups." Women Personnel Hearings, supra note 4, at 143.

69. See, e.g., Lindenau v. Alexander, 663 F.2d 68 (10th Cir. 1981) (upholding National Guard regulations banning enrollment of single parents); West v. Brown, 558 F.2d 757 (5th Cir. 1977) (upholding nonwaivable Army regulations barring enlistment of unwed parents of minor children), cert. denied, 435 U.S. 926 (1978).

70. Courts have defined sexual discrimination to include not only policies of overt discrimination, but also facially neutral policies that impact the sexes differently. For example, in a Title VII action, once a plaintiff has shown that a facially neutral employment policy has a siguificant adverse effect upon members of a protected group, the burden shifts to the employer to show that the practice has a manifest relationship to the job in question and is justifiable on the grounds of business necessity. Chambers v. Omaha Girls Club, Inc., 834 F.2d 697, 700-01 (8th Cir. 1987). To maintain the questioned practice, the employer must demonstrate a "compelling need." Id. at 701 (quoting Hawkins v. Anheuser-Busch, Inc., 677 F.2d 810, 815 (8th Cir. 1983)).

71. Several courts have found that refusal to hire unwed parents constitutes sexual discrimination because such a practice disproportionately burdens female applicants. See, e.g., King v. Trans World Airlines, Inc., 738 F. 2d 255 (8th Cir. 1984) (employer's asking unmarried female job applicant questions regarding her marital status and the legitimacy of her children, along with subsequent refusal to hire her, constituted a prima facie case of sexual discrimination under the Pregnancy Discrimination Act); Andrews v. Drew Mun. Separate School Dist., 507 F.2d 611 (5th Cir. 1975) (school district's automatic disqualification of unwed parents from employment violated equal protection rights of single women). But cf. Philips v. Martin Marietta Corp., 400 U.S. 542, 544 (1971) ("[t]he existence of . . . family obligations, if demonstrably more relevant to job performance for a woman than for a man, could arguably be a basis" for a lawful distinction under Title VII); Dolter v. Wahlert High School, 483 F. Supp 266 (N.D. Iowa 1980) (under a Bona Fide 
military is condoned. In addition, several recent studies have found sexual harassment, another form of discriminatory treatment, ${ }^{\mathbf{7 2}}$ to be a particularly egregious problem in the military. ${ }^{73}$

A 1988 Department of Defense Task Force Report found inequities in the facihties and services provided to male and female military personnel stationed abroad. ${ }^{74}$ The Report suggested that medical care provided to female servicemembers was accorded lower priority than that provided to female dependents of male servicemembers. ${ }^{75}$ The Task Force also reported that, as a result of the "less-than-adequate" facilities provided for servicewomen in some locations, female members "perceive themselves, and may be perceived by others, as less than full members of the team."76 Like the combat exclusion, these other instances of discrimination persist without sound justification. Moreover, diverse discriminatory practices may originate with the coinbat exclusion. The combat exclusion, as implemented, almost guarantees that women will remain outside the central policy and planning positions. The attitudes of military personnel, in turn, conform with the fundamentally discriminatory power structure.

III

Failed Attempts to Solve the Problem

Because the combat exclusion lies at the heart of inuch of the sex discrimination in the military, attaining greater equality and fairness for servicewomen requires either abolishing the exclusion altogether or finding ways to mitigate its discriminatory effects. But Congress, the judiciary, and the military seem reluctant to abandon or limit the exclusion. The legislature and the courts consistently reject petitions to eliminate

Occupational Qualification, sectarian school could impose a code of moral conduct precluding unwed parents as long as the asserted BFOQ was not simply pretextual).

In the context of the military, a proper examination of the parental policies should likewise involve an examination of whether the practices are necessary to the safe and efficient performance of the particular job. For example, the imquiry should be whether single parents would be unable to perform their duties reliably and effectively, especially in cases of emergency or short notice.

72. In general, the courts treat sexual harassment as a form of sexual discrimination. See, e.g., Meritor Savings Bank v. Vinson, 477 U.S. 57, 66 (1986).

73. In hearings before the House Armed Services Committee, Carolyn Becraft, Director, Women and the Military Project, Women's Equity Action League, cited the results of a 1986 and a 1987 study of military personnel in Europe and the Pacific as demonstrating that sexual harassment is the "biggest obstacle . . . that military women face in their profession today." Women Personnel Hearings, supra note 4, at 28 . The Pentagon report responding to the studies acknowledged that the problem of sexual harassment in the services is "significant." Id. at 134; see also USAF PERSONNEL STUDY, supra note 45, at 9-22 (evidencc suggesting that sexual harassment is a problem for Air Force women).

74. Women Personnel Hearings, supra note 4, at 137.

75. Id.

76. Id. 
the exclusion, and internal military channels are generally hostile to sex discrimination challenges.

\section{A. Challenging the Combat Exclusion}

Congressional proposals to repeal the combat exclusion may lead to its eventual abolition. At a minimum, the debate and discussion engendered by such proposals should underscore the lack of a coherent justification for the exclusion and point toward ways to lessen its impact. By bringing attention to the contributions of the growing number of women in the military such proposals may lessen the public antipathy towards the notion of abohishing the combat exclusion.

In the short run, however, such proposals are unlikely to pass. Previous legislative attempts to abohish the combat exclusion have failed, ${ }^{77}$ partly because the American public has seemed committed to maintammg some sort of distinction between men and women in combat. Public opposition to women serving in combat positions remains a substantial pohitical obstacle to repeal. ${ }^{78}$ Since a legislative repeal of the combat exclusion does not appear to be politically feasible at this time, other options to address sex discrimination in the military must be explored.

For a variety of reasons, legal challenges to the combat exclusion appear equally futile at the present. Any challenge to the combat exclusion on equal protection grounds ${ }^{79}$ would almost certainly fail, as the courts generally refrain from exercising more than a cursory review of military policy. ${ }^{80}$ Even when the courts undertake to review military

77. See, e.g., Legislative Calendar, House Armed Services Comm., 94th Cong., Final Calendar 1975-1976 (1976), at 13 (H.R. 58), 26 (H.R. 2190), 73 (H.R. 12649).

78. One commentator stated the issue concisely, when she noted that in any discussion of equality between the sexes, the subject of combat is where we reach our "cultural limit." "[S]peculate for a moment about where society might draw the lime and refuse to proceed further with gender equality .... Surely, one rather indisputable answer to that question is 'war': physical combat and its modern equivalents." Williams, The Equality Crisis: Some Reflections on Culture, Courts, and Feminism, 7 WOMEN's RTS. L. REP. 175, 183 (1982).

79. A constitutional claim would appear to be the only avenue for court review of a discrimination claim by a servicewoman. As the law presently stands, Title VII does not appear to provide a remedy to members of the uniformed military. See infra notes 115-19 and accompanying text.

80. A balancing test, which weighs the nature and strength of a plaintiff's claim against the cost of intrusion into military affairs and the degree of military expertise required, determines the appropriateness of hearing a constitutional or statutory claim against the military. Mindes v. Seaman, 453 F.2d 197, 201 (5th Cir. 1971). Under this test, an equal protection challenge to the combat exclusion would be unlikely ever to reach the merits, since questions regarding personnel designations-particularly combat-would appear to intrude into the heart of military decisionmaking. See Lindenau v. Alexander, 663 F.2d 68 (10th Cir. 1981) (equal protection grounds for challenge to National Guard regulation prohibiting enlistment of single parents with minor children held insufficient to warrant the court's examination of personnel policy decision requiring military expertise). A majority of circuits have adopted this balancing test for deciding the initial question of justiciability of claims against the military. See Note, Judicial Review of Constitutional 
decisions, they emphasize that judicial deference necessitates a very weak standard of review in all questions implicating military preparedness. ${ }^{81}$ Thus, a realistic attack on sex discrimination in the inilitary would not seek to overturn the combat exclusion, but would instead attempt to limit the exclusion's discriminatory impact. An examination of intramilitary remedies for discrimination reveals whether the present system could be capable of effecting such a result.

\section{B. Using Current Intramilitary Remedies to Challenge Discrimination}

Uniformed military personnel have three options for advancing claims of discrimination: file a complaint under the Department of Defense Equal Opportunity Program, ${ }^{82}$ pursue a claim under Article 138 of the Uniform Code of Military Justice (UCMJ), ${ }^{83}$ or proceed before the Board of Correction of Military Records. ${ }^{84}$ These avenues are inadequate for a variety of reasons, including limited scope of reviewable claims, lack of uniform legal standards, counterproductive and ambiguous procedural guidelines, and insufficient external review.

The Departinent of Defense Equal Opportunity Program (DoDEOP) allows a servicemember to bring a complaimt alleging "arbitrary discrimination" 85 based on gender. The program focuses primarily on educating servicemembers in hunian relations ${ }^{86}$ and enforcing nondiscriminatory use of military facilities and resources. ${ }^{87}$ It differs substantially from other federal agencies' equal opportunity prograns because it

Claims Against the Military, 84 Colum. L. REv. 387, 397 \& n.57 (1984) (authored by Gabriel Gorenstein) (citing the adoption of the "Mindes test" in eight circuits).

81. The Supreine Court in Rostker v. Goldberg, 453 U.S. 57 (1981), finding the inale-only draft registration constitutional, paid lipservice to the established standard that gender-based classifications inust be substantially related to important governmental objectives. Id. at 69-72 (citing Craig v. Boren, 429 U.S. 190 (1976)). The Rostker Court's highly deferential review lead several federal district courts to read Rostker as a rejection of the inore rigorous Craig standard when gender-based equal protection claims involve the inilitary. See, e.g., Lewis v. United States Army, 697 F. Supp. 1385, 1390 n.5 (E.D. Pa. 1988) ("Based on iny reading of Rostker . . I I conclude that the standard outlined in Craig is not applicable to gender-based equal protection claims raised in the context of military affairs . . . "); Mack v. Rumsfeld, 609 F. Supp. 1561, 1564 (W.D.N.Y. 1985) (military regulation treated as "presumptively valid and constitutional if . . . reasonably relevant and necessary to further national defense"), aff'd, 782 F.2d 356 (2d Cir. 1986), amended, 784 F.2d 438 (2d Cir. 1986), ccrt. denied, 479 U.S. 815 (1986); Cobb v. United States Merchant Marine Academy, 592 F. Supp. 640, 644 (E.D.N.Y. 1984) ("Naval reserve policy of not coinmissioning pregnant persons is not only rational, but is rational to such a degree as to make it unequivocally clear that the policy is not violative of the Fifth Amendment Due Process Clause.").

82. 32 C.F.R. $\$ 191$ (1988); see also Note, Making The Army Safe for Diversity: A Title VII Remedy for Discrimination in the Military, 96 YALE L.J. 2082, 2086 \& n.32 (1987) (authored by Mary Griffin).

83. Uniform Code of Military Jnstice, Art 138, 10 U.S.C. $\S 938$ (1988).

84. 10 U.S.C. $\$ 1552$ (1988).

85. 32 C.F.R. $\$ 191.4(\mathrm{a})$ (1988)

86. See id. \& 191.5(b)(12).

87. See id. \& 191.4(d)-(f). 
is outside the jurisdiction of the Equal Employment Opportunity Commission (EEOC) ${ }^{88}$ As a result, the EEOC has no power to investigate or take action on charges of discrimination in the uniformed military, and the DoD-EOP does not apply the standard equal opporturity guidelines and procedural regulations. ${ }^{89}$

Instead, the Departinent of Defense remedy provides that the Assistant Secretary of Defense or head of each DoD coinponent shall "[r]eview and take action on, as appropriate, investigations . . . or discrimination coinplaints received by the DoD," "[t]ake appropriate disciplinary action" for arbitrary acts of discrimination, and "[e]nsure that Mihtary Equal Opportunity and discrimination investigations are coordinated with appropriate ... officers." 90 No specific guidelines explain the procedure a complainant inust follow, nor are any procedures set forth for adequate investigation of coinplaints. Complaints are handled primarily through the cham of coinmand $;{ }^{91}$ thus a coinplainant must bring her grievance directly to her superior, the likely subject of the coinplaint. ${ }^{92}$ Appointment of an independent investigator is discretionary, and no provision sets forth procedures to be followed in such a situation. ${ }^{93}$

Under the second option for advancing a claim of discrimination in the military, a serviceineinber may bring an Article 138 general grievance proceeding after "due application to that commanding officer is refused redress." 94 The aggrieved party inay then complain to a superior officer, who forwards the coinplaint to the officer exercising general court-1nartial jurisdiction over the coinplained-of officer. The officer exercising jurisdiction conducts an inquiry, takes "proper measures for redressing the wrong," and sends a stateinent of the complaint and any proceedings to the military departinent secretary. ${ }^{95}$ No guidelines define "proper

88. See Gonzalez v. Department of Army, 718 F.2d 926, 927-28 (9th Cir. 1983). When section 717(a) of Title VII extended the Civil Rights Act of 1964 to the "military departments" and transferred the Civil Service Commission's enforcement function to the EEOC, it was not meant to extend that authority to uniformed personnel. The court in Gonzalez stated that, "There is no indication in the legislative history that the former jurisdiction of the Civil Service Commission was to be expanded upon the transfer of functions to the EEOC. Moreover it is abundantly clear that the Civil Service Commission was never authorized to review or police discrimination within the armed forces." Id. at 928 . (citation omitted).

89. See, e.g., 32 C.F.R. § 191.2(c) (1988); cf. 42 U.S.C. $\$ 2000 \mathrm{e}-16$ (1982).

90. 32 C.F.R. $\S \S 191.5(\mathrm{a})(8),(\mathrm{b})(8),(\mathrm{b})(14)$ (1988).

91. Id. $\$ 191.4(\mathrm{~g})$.

92. See Women Personnel Hearings, supra note 4, at 57 (testinony of Rep. Beverly Byron, Chairperson, Military Personnel and Compensation Subcommittee).

93. See Note, supra note 82, at 2087 n.34 (quoting Army Reg. No. 600-21 (1977): "When appropriate an independent investigator should be appointed. Personnel assigned to [Equal Opportunity] offices should be consulted . . . in the resolution of complaints of discrimination but should not be used to investigate such inatters.").

94. Uniform Code of Military Justice, Art. 138, 10 U.S.C. $\S 938$ (1988).

95. Id. 
measures," nor are accountability procedures set forth to assure that a complaint is not halted within the chain of command.

Thus, under both the DoD-EOP and UCMJ procedures, a servicewoman must pursue her complaint of discrimination through the chain of command; the regulations offer her no alternative grievance channels. The prospect of depending on the military chain of command for relief may discourage many women from bringing discrimination claims. A female servicemember wishing to bring a complaint of discrimination must often first present her claim to the offending officer-an unpleasant and discouraging task. The superior officers who next review a claim may give little credence to complaints against their colleagues brought by lower ranking servicemembers. ${ }^{96}$ Many servicemembers apparently believe that such claims of discrimination processed under these circumstances will go unheeded ${ }^{97}$ or provoke retahatory action. ${ }^{98}$ Discrimination may therefore persist without complaint, under a chain-of-command system "perceived as a participant in, or thought to condone, pejorative attitudes toward military women." 99

The only intramilitary remedy for discrimination that does not rely on the chain of command is an appeal to a Board of Corrections of Military Records (BCMR), a body composed of Defense Department civilian executives. BCMR members do not necessarily have legal training and the board lacks authority to make law or invalidate challenged regulations. ${ }^{100}$ Rather, the boards have authority only to "correct an error or

96. Where discrimination is so widespread that the superior officer is more likely to sympathize with the offender than with the victim, a grievance procedure under that officer's control is unlikely to address the complaint. See Tufts v. Bishop, S51 F. Supp. 1048 (D. Kan. 1982) (superiors allegedly quashed investigation of sexual discrimination complaint filed against them by female Air Force member); see also Bois v. Marsh, 801 F.2d 462 (D.C. Cir. 1986) (female Army captain's immediate supervisor was allegedly pressured into supporting another superior officer's discriminatory acts against the captain).

97. See Stubbs v. United States, 744 F.2d 58, 59, 61 (8th Cir. 1984) (feinale soldier who committed suicide after being sexually assaulted by her drill sergeant allegedly believed that superior officers would not respond to her grievance), cert. denied, 471 U.S. 1053 (1985); see also United States v. Roberts, 14 M.J. 671, 673 (N.M.C.M.R. 1982) (court-martial charges of unauthorized absence against female sailor disınissed on duress defense where defendant had been subjected to sexual harassment, reasonably feared further bodily injury, and had complained unsuccessfully to superior officers), rev'd on other grounds, 15 M.J. 106 (C.M.A. 1983).

98. The Department of Defense Task Force on Women in the Military noted in its 1988 Report that in some instances procedures for complaints of sexual harassinent within the military are "not well-used, apparently because of concern that filing a complaint might adversely impact the member's career or bring retribution." Women Personnel Hearings, supra note 4, at 136; see also Note, Making Intramilitary Tort Law More Civil: A Proposed Reform of the Feres Doctrine, 95 YALE L.J. 992, 1002 n.40 (1986) (authored by David Saul Schwartz) (citing disciplinary actions against soldiers who presented controversial grievances).

99. Women Personnel Hearings, supra note 4, at 136 (Report of Departinent of Defense Task Force on Woinen in the Military).

100. Glines v. Wade, 586 F.2d 675, 678 (9th Cir. 1978), rev'd on other grounds, Brown v. Glines, 444 U.S. 348 (1980). 
reinove an injustice" ${ }^{101}$ in an individual's military records. ${ }^{102}$ However, the regulations provide no investigation procedures or standards defining "injustice." Nor are complainants guaranteed a hearing before the board: a board may inake determinations on applications without a hearing. ${ }^{103}$ Furthermore, civilian courts traditionally defer to BCMR decisions. A servicenember challenging a board's decision carries the "difficult standard of proof" that the decision was arbitrary, capricious, unlawful, or unsupported by substantial evidence. ${ }^{104}$

Thus, all three of the intramilitary remedies rely on ad-hoc procedures that leave a high degree of discretion to military officials. No clear standards or procedures exist to define an adequate investigation or resolution of a claim. Moreover, complainants have difficulty knowing when they have adequately exhausted intramilitary renedies and earned the right to appeal to a civilian court. ${ }^{105}$

Because coinplaint procedures are poorly defined, widespread discriunination may persist without coming under any substantive inquiry or review. ${ }^{106}$ By leaving the military to police itself, the present intramilitary reinedial system may encourage inembers to cover up discrimination and thus avoid public criticisin, rather than to investigate proinptly and resolve problems of discrimination. ${ }^{107}$

Furthermore, the military justice system may be ill-suited to deter

101. 10 U.S.C. § 1552(a) (1988).

102. The regulations governing each service's board are set forth in the Code of Federal Regulations: 32 C.F.R. $\S 581.3$ (1988) (Army); 32 C.F.R. $\S 723.1-11$ (1988) (Navy and Marine Corps); 32 C.F.R. $\S 865.0-29$ (1988) (Air Force); and 33 C.F.R. $\S 52.01-1$ to .45-5 (1988) (Coast Guard).

103. See, e.g., 32 C.F.R. \& 723.3(e) (1988).

104. Sanders v. United States, 594 F.2d 804, 811 (Ct. Cl.), later proceeding, $221 \mathrm{Ct}$. Cl. 988 (1979).

105. The experience of the plaintiff in Hill v. Berkman, 635 F. Supp. 1228 (E.D.N.Y. 1986) is demonstrative. Originally, Hill brought her discrimination claim to her superior officer, who was also an EEO officer. She then pursued her complaint up the chain of command, as directed, until a final agency decision gave her a "right to sue" letter. The Army then defended against the suit on the ground that Hill had failed to exhaust her administrative remedies by not seeking redress at the Army Board for Correction of Military Records (ABCMR). However, the ABCMR possessed no jurisdiction to review Hill's honorable discharge. Note, supra note 82, at 2088 n.38. See Glines v. Wade, 586 F.2d 675, 678 (9th Cir. 1978) (Air Force BCMR had no authority to declare challenged regulation invalid, thus plaintiff was not required to first seck relief from AFBCMR); Saal v. Middendorf, 427 F. Supp. 192, 197 (N.D. Cal. 1977) (by issuing an honorable discharge, the Navy "effectively precluded review ... by the Board for Correction of Naval Records for there [was] no record left to correct"), rev'd on other grounds, Beller v. Middendorf, 632 F.2d 788 (9th Cir. 1980), cert. denied, 454 U.S. 855 (1981).

106. Several commentators have noted the military's resistance to addressing widespread, institutional discrimination. See, e.g., Howland, The Hands-Off Policy and Intramilitary Torts, 71 IowA L. REv. 93, 134 n.262 (1985); Note, supra note 82, at 2087 n.38 (citing R. RIVkiN, G.I. Rights AND ARMy Justice 181-83 (1970) and R. Rivkin \& B. Steichman, The Righrs of MiLITARy PersonNel 122-30 (1977)).

107. See Women Personnel Hearings, supra note 4, at 58-59 (testimony of Rep. Patricia Schroeder). 
discrimination since it is designed to enforce discipline, not to proinote individual rights or societal norms of equity. ${ }^{108}$ Officers are trained in the pursuit of military effectiveness, a goal generally perceived as incompatible with individual liberties. "One who believes himself bound by and complying with this code of self-denial and subordination cannot be expected to completely syinpathize with contrary values of diversity and autono1ny"109 implicit in claims of discrimination.

In sum, the existing military remedial system cannot successfully eradicate the discriminatory practices fostered by the combat exclusion. The problem of sex discrimination in the military requires the creation of a new remedy that will eliminate inuch of the discrimination originating with the amorphous combat exclusion. The application of Title VII to the uniformed military would be such a remedy.

VI

\section{Proposal: Application of Title VII to the UNIFORMED MILITARY}

Title VII of the Civil Rights Act of $1964^{110}$ is the primary federal law used to combat employinent discrimination based on race, religion, sex, or national origin. The statute addresses both "disparate treatment" of protected groups and the "disparate impact" of certain policies on such groups. Disparate treatment involves overt or intentional discrimination against an individual based upon her membership in a protected group. ${ }^{111}$ Disparate impact refers to facially neutral policies that disproportionately burden a protected group. ${ }^{112}$ Title VII allows use of a protected classification as an employment criteria only if the classification is based upon a bona fide occupational qualification (BFOQ). ${ }^{113}$ Similarly, an einployinent qualification or requirement that disproportionately excludes a protected group must be shown to be a "business necessity," rather than a inere cover for outright discrimination. ${ }^{114}$

Almost without exception, the courts have found that Title VII, as presently formulated, does not apply to the uniformed military. ${ }^{115}$ Title VII's ainending legislation extends coverage to "employees or applicants

108. See Note, supra note 82 , at 2088 \& n.39 (1987).

109. Hirschhom, The Separate Community: Military Uniqueness and Servicemen's Constitutional Rights, 62 N.C.L. REV. 177, 242 (1984).

110. 42 U.S.C $\$ 2000 \mathrm{e}-2000 \mathrm{e}-17$ (1982).

111. See International Bhd. of Teamsters v. United States, 431 U.S. 324, 335 n.15 (1977).

112. Id.

113. 42 U.S.C. $\S 2000 \mathrm{e}-2(\mathrm{e})(1982)$.

114. See supra note 70.

115. See, e.g., Johnson v. Alexander, 572 F.2d 1219, 1224 (8th Cir.) (if Congress had intended to apply Title VII to the uniformed military it would have said so explicitly), cert. denied, 439 U.S. 986 (1978); Gonzalez v. Department of Army, 718 F.2d 926, 928 (9th Cir. 1983) ("military departments" in the statute refers to civilian employees and not uniformed personnel). Hill $v$. 
$\ldots$ in the military departments," 116 but fails to define who is encompassed within the "military departments" for purposes of the statute. ${ }^{117}$ Significantly, the legislative history is silent on whether Congress intended to mclude uniformed military personnel as well as civilians in the amendment's scope. The legislature's silence strongly suggests that Congress did not intend to apply Title VII to the uniformed military. Since the courts traditionally refuse to find a remedy for discrimination claims against the military, ${ }^{118}$ it is highly unlikely Congress would have remained silent had it intended to provide a Title VII remedy to unformed personnel. ${ }^{119}$ Moreover, because the legislative record contains no discussion of the issue, it appears that Congress never even considered extending Title VII in this way. ${ }^{120}$

The time has coine for Congress to ainend Title VII to extend its protection to the uniformed mihtary. ${ }^{121}$ Such an amendment would

Berkman, 635 F. Supp. 1228 (E.D.N.Y. 1986) stands as the only case holding that Title VII apphes to the uniformed military.

The Second Circuit in Roper v. Department of Army, 832 F.2d 247 (2d Cir. 1987), was sympathetic to the Hill court's policy arguments, but declined to extend Title VII protection to the "dissimilar employment context of the [uniformed] military." Id. at 248. For a critique of the Gonzalez, Johnson, and Hill opinions, see Note, supra note 82, at 2089-95.

116. Equal Employment Opportunity Act of 1972, Pub. L. No. 92-261, 86 Stat. 111 (1972) (codified as amended at 42 U.S.C. § 2000e-16(a) (1982)).

117. Id. Nor does the statute's reference to the definition of "military departments" in 5 U.S.C $\S 102$ help, as that section states in its entirety, "The military departments are: The Department of the Army[] The Department of the Navy [and the] The Department of the Air Force." 5 U.S.C. $\S 102$ (1982).

118. See, e.g., Chappell v. Wallace, 462 U.S. 296, 304-05 (1983) (dechining to provide a remedy for a claim of race discrimination in inilitary work assignments, given Congress' silence regarding such a cause of action and the "urique disciplinary structure of the Military Establishment").

119. Cf. Feres v. United States, 340 U.S. 135, 144 (1950) (even assuming that the Federal Tort Claims Act might be read to allow tort actions for a soldier injured in service, Congress did not state its intention of such a result and thus the courts should not permit such a remedy).

120. Even if Title VII as presently formulated were held to apply to uniformed members of the military, the use of the statute for claims of discrimination in the military would still be problematic. The courts would probably contimue to defer to military policy when considering claims brought under the statute. The Hill opinion clearly demonstrates this, concluding that the test for policy decisions is "whether the military decision was clearly arbitrary and erroneous, with a harmful effect present at the time the dispute reaches the court." Hill v. Berkman, 635 F. Supp. 1228, 1241 (E.D.N.Y. 1986). Application of this test in numerous military cases could threaten to spill over into civilian Title VII litigation and seriously weaken the established standards. Congress could prevent such a result by guiding the courts' application of Title VII in military claims cases with express language.

121. Such an amendment would be consistent with earlier amendments that expanded Title VII's scope. Before Title VII was amended in 1972 there was "serious doubt that court review [was] available to the aggrieved Federal employee" who had suffered employment discrimination. H.R. REP. No. 238, 92d Cong., 1st Sess. 25, reprinted in 1972 U.S. CODE CONG. \& ADMIN. NEws 2137, 2160. Congress amended the law to afford federal "employees or applicants the full rights available in the courts as are granted to individuals in the private sector under Title VII." Hill, $635 \mathrm{~F}$. Supp. at 1233 (quoting S. Rep. No. 415, 92d Cong., 1st Sess. 16 (1979)).

In 1978 Congress amended Title VII again, placing preguant women decisively within the statute's protection by passing the Preguancy Discrimination Act of 1978, Pub. L. No. 95-555, § 1, 
institutionalize effective non-discrimination policies and procedures within the military. The new Title VII amendinent could be drafted to leave intact a statutory combat exclusion, while limiting the exclusion's use as a justification for other discriminatory policies. Congress would need to establish guidelines for applying the exclusion. The services would then be required to use the guidelines when classifying inilitary positions. This process would ensure that the combat exclusion would be apphed only to the extent justified in tle Congressional guidelines. Furthermore, for the first time, Congress would give the courts an express mandate to inquire into the military's reasons for coinbat and noncombat classifications. The courts could derive judicial standards from the statutory language, and to tlie extent required, from the legislative history of the amendment.

The amendment sliould read:

"Military departments, as provided in Sec. 2000e-16(a), shall mclude umformed personnel. This section shall not preclude classification of combat as a bona fide occupational qualification, as defined in Sec. 2000e-2(e)."

\section{A. How the Proposal Would Affect the Combat Exclusion and Discrimination}

Assurning the combat exclusion continues, the legislation should set forth the bona fide occupational qualification that justifies the exclusion. ${ }^{122}$ In this way, the amendinent itself would not call into question the validity of the statutory combat exclusion. ${ }^{123}$ Nonetheless, tlie impo-

92 Stat. 2076 (currently codified at 42 U.S.C. $\$ 2000$ e (1982)). Congress thus reversed the Supreme Court's decision in General Elec. Co. v. Gilbert, 429 U.S. 125 (1979), reh'g denied, 429 U.S. 1079 (1977), which held that discrimination against pregnant woinen in a disability benefits plan does not constitute sex-based discrimination under Title VII.

122. Section 703(e) of Title VII permits sex-based discrimination where the reason for the discrimination is a "bona fide occupational qualification" (BFOQ). 42 U.S.C § 2000e-2(e) (1982). One widely used test for determining whether a particular job inay be classified under the BFOQ exception is whether "all or substantially all women would be unable to perform ... the duties of the job ...." Weeks v. Southern Bell Tel. \& Tel. Co., 408 F.2d 228, 235 (5th Cir. 1969); see also Diaz v. Pan Am. World Airways, 442 F.2d 385, 388 (5th Cir.) ("discrimination based on sex is valid only when the essence of the business operation would be undermined by not hiring members of one sex exclusively") (emphasis in original), cert. denied, 404 U.S. 950 (1971).

123. The constitutionality of the male-only draft registration depends in part upon the combat exclusion. Faced with an equal protection challenge, the Supreme Court has used the combat exclusion to uphold the male-only draft. Rostker v. Goldberg, 453 U.S. 57 (1981). Applying Title VII to the military while leaving the combat exclusion intact, as proposed here, would not call Roskter into question. But if the application of Title VII led the services to open a significant number of positions to women, Congress might on its own initiative unove to register women as well as men. Congressional antipathy towards registering women may already be lessening; Congress has recently investigated the possibility of gender-neutral draft registration in certain medical occupations. See N.Y. Times, Apr. 20, 1989, at A18, col. 1. 
sition of Title VII would strictly limit the scope of the combat exclusion and its harmful side effects.

Congress would need to articulate its rationale for the combat exclusion so that the military could define combat positions in reference to that rationale. But a BFOQ to protect the combat exclusion should not be treated differently from other exceptions to the general mandate of Title VII. Application of the statute will be effective only if the same standards are applied to claims in the uniformed military as are applied to other Title VII claims. Thus, to be consistent with the rules it has provided the EEOC, Congress should formulate a rationale for the combat exclusion in terms that distinguish men and women based on something more than a "stereotyped characterization of the sexes." 124

Only after Congress has examined and explained the purpose for the coinbat exclusion can the military formulate a coherent definition of combat and a consistent system for classifying positions. The boundaries of the combat exclusion would become much clearer than in the past, since any change in the definition of combat or of combat classifications would need to conform with Congress' original rationale for the exclusion.

For the legislation to be effective, the scope of a permissible BFOQ exception, and thus the scope of the combat exclusion, should remam "narrow."125 Accordingly, the combat exclusion would apply ouly to a strictly limited number of occupations, and the courts could review any coinbat classification to determine whether it achieves the specified purpose. Thus, the military, hike other Title VII employers, would have to show why differential treatment of women is warranted. ${ }^{126}$

The inplementation of Title VII would grant female servicemembers a remedy for individual instances of discrimination and harassment, as well as for discriminatory military policies and procedures. The standards for the military under Title VII should be the same as those applied to all employers subject to Title VII. The legislation "precludes treatment of individuals as simply components"127 of a

124. See 29 C.F.R. $§ 1604.2$ (a)(1)(ii) (1988) (refusal to hire an individual based on stereotypical characterizations of the sexes is not a valid application of the BFOQ exception).

125. Cf. Dothard v. Rawlinson, 433 U.S. 321, 334 (1977) (Court nevertheless found that the "jungle atmosphere" in Alabama's penitentiaries justified the state's exclusion of women from prison guard employment).

126. See, e.g., id. at 336 (male-only "contact" guard classification valid where substantial testimony from both sides supported the proposition that use of female guards would pose a serious threat to the "security that is the essence of a correctional counselor's responsibility"); Diaz v. Pan Am. World Airways, Inc., 442 F.2d. 385, 389 (5th Cir.) (inability of most males to master nonmechanical aspects of a flight attendant position does not adequately justify excluding all males from such positions where the nonmechanical aspects demanded are merely "tangential" to the airline's business), cert. denied, 404 U.S. 950 (1971).

127. Los Angeles Dep’t of Water \& Power v. Manhart, 435 U.S. 702, 708 (1978). 
gender class. Even a statistically valid generalization about women would be an insufficient reason for disqualifying a particular woman to whoin the generalization does not apply. ${ }^{128}$

Possibly the inost significant effect of applying Title VII to the uniformed military would be its eventual impact on the attitudes of military personnel toward woinen. If the combat exclusion and any other genderbased restrictions were constrained to fit within legally supportable justifications, distinctions between men and woinen in the military would become less pervasive. Decisionınakers in the military would be required to treat inen and woinen as equals, and could no longer assume that female meinbers are soineliow out of place im the military. An unjustified distinction between the sexes would no longer serve as the springboard for other sex-based distinctions.

Witl Title VII in place, the military would have consistent guidelines to follow in employinent practices and grievance procedures. Altliough military procedures would still govern complaints at the initial stages, the system would be effectively policed by the possibility of substantive judicial review of inilitary findings and decisions.

\section{B. How It Would Work}

Title VII sliould be applied in conjunction with changes in the present intramilitary reinedial scheme. The military's reliance on the chain of command sliould be replaced by a inodel similar to the EEO procedure presently available to civilian Army einployees. Under this procedure, EEO counselors and officers outside of an individual's chain of coinmand would investigate and reconcile discrimination claims. ${ }^{129}$ Verifiable standards and procedures would set fortli intramilitary adıninistrative remedies to be exliausted before resorting to civilian courts. ${ }^{130}$

Before filing a formal complaint, servicennembers would be required to present the matter to an EEO counselor who would inquire into the matter and counsel the complainant. ${ }^{131}$ After he completes his investigation the counselor would document his preliminary findings and attempt to resolve the matter informally. ${ }^{132}$ The aggrieved member would then gam the riglit to file a formal complaint with an EEO officer. ${ }^{133}$ Specific criteria for accepting a complaint, sucl as whetler the alleged violation was properly within the scope of the statute and timely filed, would guide

\footnotetext{
128. Id.

129. See 32 C.F.R. $\S \S 588.17-.20$ (1988).

130. See id. $\S \S 588.57-.59$.

131. See id. $\S 588.13$.

132. See id. § 588.13(c), (d)(1), (d)(3).

133. See id. $\S 588.14$.
} 
EEO officers when examining claims. ${ }^{134}$ Further investigation would follow, and the counselor would suggest an adjustment meeting to reach an agreenent with the complainant. ${ }^{135}$ Finally, the appropriate activity commander would issue a proposed disposition to be adopted unless the complainant requests an EEOC hearing or a military decision without a hearing. ${ }^{136}$ After a final military decision, the complainant would also have the right to bring a civil action, rather than an appeal to the EEOC. ${ }^{137}$

Thus, servicemembers would gain the same guarantee of equal treatment in employment that other federal employees enjoy. The military, however, would retain substantial first-step control im reconciling claims of discrimination. The proposed procedures would provide an unainbiguous and effective method for resolving complaints of discrimination within the military. ${ }^{138}$ This would aid military efficacy by identifying and resolving personnel problems which might otherwise become buried in the bureaucracy of intramilitary claims. Even if adopting such procedures would not in itself change long-standing prejudices, the military bureaucracy's desire to avoid civil judicial review and sanctions would encourage it to resolve claims of discrimination adequately. Furthermore, civilian courts would have available a clear record of findings from below, as well as standards and guidelines by which to judge an employment decision.

\section{An Evaluation of the Proposal's Potential Harm}

The proposed legislation would give courts an express mandate to inquire into clamis of discrimination in the military. The statute would represent a congressional determination that equahty concerns are not autonatically trumped by claims of military necessity. Before this mandate is given to the courts, Congress must examine the legislation's probable impact upon military effectiveness through its effects on military discipline, decisionmaking, and overall strength.

\section{Military Discipline}

One reason advanced for judicial deference to the military is the fear that servicemembers' recourse to the courts would disrupt military discipline. The Supreme Court has noted that the military is a "specialized society separate from civihan society," 139 where the rights of the

\footnotetext{
134. See id. $\S 588.15$.

135. See id. $\$ 588.20$.

136. See id.

137. See id. §588.59.

138. See Hill v. Berkman, 635 F. Supp. 1228, 1238 (E.D.N.Y. 1986).

139. Parker v. Levy, 417 U.S. 733, 743 (1974).
} 
individual are subordinated to the goals of the organization. Individual rights are subject to "certain overriding denands of discipline and duty" in the military. ${ }^{140}$ Along these lines, it is argued that if courts permit servicemembers to bring civil actions to enforce individual liberties contrary to a superior officer's orders, military discipline could become seriously disrupted. Making civilian judges the final arbiter of such claims would destroy the essential image of unquestioned military authority. ${ }^{141}$

The theory that military discipline requires unquestioned obedience to authority, however, is not universally accepted. Soine inilitary sociologists have suggested that military discipline appears more directly related to the character of a soldier's "primary group," than to his or her unthinking acceptance of formal authority. ${ }^{142}$ These sociologists suggest that soldiers devote themselves to the military goal because of their inutual dependence upon one another and upon their superiors. According to this view, discipline is enforced through the threat of disapproval and ostracism from the soldier's primary group. ${ }^{143}$

If cohesion and mutual dependence of soldiers' primary units strengthens military discipline, then the effective policing of discriminatory practices within the military might actually enhance discipline. Reinoving unfounded distinctions that can create dissension ${ }^{144}$ and antagonisin could foster a stronger sense of unity within the military group. Therefore, military discipline might be improved by remedying discrimination within the inilitary. Moreover, if servicemembers believe that the military treats its personnel fairly, they may be more likely to accept and meet the demands of their jobs. ${ }^{145}$

It is unlikely that claims of discrimination would negatively affect military discipline in the anticipated manner. In contrast to some types of civil hiberties claims, plaintiffs claiming discrinination rarely demand the right to defy inilitary orders. A contrast can be shown to a plaintiff soldier asserting an action for freedom of speech. There, if a court ruled for the plaintiff soldier, invariably the court's order would directly conflict with inilitary discipline by permitting the soldier to express herself in

140. Burns v. Wilson, 346 U.S. 137, 140 (1953) (plurality opinion).

141. See Chappell v. Wallace, 462 U.S. 296, 304 (1983) ("[W]e must be 'concern[ed] with the disruption of the peculiar and special relationship of the soldier to his superiors that might result if the soldier were allowed to hale his superiors into court.' ") (quoting Stencel Aero Eng'g Corp. v. United States, 431 U.S. 666, 676 (1977) (Marshall, J., dissenting)).

142. E.g., N. KeiJzer, Military ObedienCE 53-66 (1978).

143. E.g., id. at 55 .

144. For a brief survey of studies documenting military dissension created by racially discriminatory practices, see Note, supra note 82 , at 2098-99.

145. Cf. Hirschhorn, supra note 109, at 206-07 (1984) (citing judicial and nonlegal commentary arguing that "judicial imposition of civilian norms on the armed forces would increase military effectiveness"). 
a manner directly opposed to orders. ${ }^{146}$ If successful, such action may in fact adversely affect military discipline, in that orders to be silent could then be openly defied on civil liberties grounds. In contrast, a court hearing a discrimination claim does not focus on the plaintiff's actions, but ratler, on the actions of the defendant. The plaintiff is asking for the defendant to accord equal treatment to all equally qualified servicemembers regardless of sex. Thus, the court would seldom rule on whether imdividuals may act contrary to military rules, but instead would judge military employment decisions and individual officers' practices. ${ }^{147}$

\section{Military Decisionmaking}

Judicial deference to the military also grows out of concern over the competence of civilian courts to review military decisions. Adherents to this view would assert that applying Title VII to uniformed personnel would draw the courts into decisionmaking properly left to the military. But there is no reason the courts would not be as qualified to rule on issues of equity and justice in military matters as they are in other Title VII contexts that require particular technical expertise. ${ }^{148}$

The military, on the other hand, has tended to shortchange important social values; in some instances it has resisted nondiscrimination measures even at the expense of military preparedness. ${ }^{149}$ The courts' experience in adjudicating Title VII claims suggests that they would be coinpetent to resolve claims of sexual discrimination in the military. After all, distinguishing between inilitary necessity and arbitrary discrimination is similar to other traditional judicial functions and would not necessarily involve the courts in strategic matters.

\section{Military Selectivity}

Finally, Title VII's mandate of equal treatment must be examined

\footnotetext{
146. See Brown v. Glines, 444 U.S. 348, 354 (1980) ("Speech likely to interfere with [the] vital prerequisites for military effectiveness therefore can be excluded from a military base.").

147. See generally Note, supra note 82 , at 2101.

148. For example, courts have evaluated the hiring practices of correctional institutions and police departments/institutions whose employees' morale, discipline, and physical capabilities are critical. See, e.g., Dothard v. Rawlinson, 433 U.S. 321 (1977) (Court rejected the height and weight requirements for Alabama prison guards but accepted the exclusion of women from all "contact" guard positions in an all-male maximum security penitentiary under Title VII's BFOQ exception); Horace v. City of Pontiac, 624 F.2d 765 (6th Cir. 1980) (city's height requirement for patrol police officers violated Title VII, because it had a disparate impact on women and served no legitimate purpose); Bagley v. Watson, 579 F. Supp. 1099 (D. Or. 1983) (male inmates' preferences did not justify discrimination against female prison guards under Title VII's BFOQ exception where there was no showing that women would be unable to safely and efficiently perform required tasks including searches),

149. See Hirschhorn, supra note 109, at 243 (even after World War II combat experience demonstrated greater effectiveness of racially integrated units, a presidential order was still necessary to end Army segregation).
} 
for its potential effect on the qualifications of military recruits. Those opposing equal opportunities for women im the military assert that such reforms would require lowering personnel standards, thereby weakening the armed forces. ${ }^{150}$ Similar fears voiced prior to opening nonconibat jobs to womien have not been borne out. ${ }^{151}$ Iniplenientation of Title VII in the uniformed military would not decrease nilitary proficiency either.

Title VII does not force enuployers to lower their standards in order to einploy both sexes. To the contrary, it requires that job requirements be based on the actual demands of the job and not on what are usually irrelevant factors such as gender. ${ }^{152}$ In fact, Title VII's directive night have beneficial results for military capabilities. Personnel would be more effectively utilized, as their placement and promotion would more likely be based upon individual skills and abilities, without regard for the biases or stereotyped views of those making such eniploynent decisions. ${ }^{153}$ Also, the elimination of artificial distinctions separating all-male and sexintegrated units could help to improve military response and reaction time. If sex-based restrictions were apphed only to functional combat positions, officers would be able to draw upon a larger reserve of personnel for a variety of tasks, and would enjoy greater flexibility in responding to emergency situations.

\section{CONCLUSION}

The military exerts great influence on our society. To the extent that discriminatory policies are accepted and sanctioned within the nilitary, the battle for women's equality in our society beconies even more onerous. Accepting for the present that our society reinams committed to a conibat exclusion for women, nuch progress in improving women's opportumities within the military can still be made. Expansion of Title VII protection to the uniformed military would ensure that women only be excluded from a military role based on a defensible justification.

150. For example, in testimony before Congress, opponents of women's admission to the service academies stated the concern that accommodating women in the military academies would inevitably weaken the entire military system. See Academy Hearings, supra note 48, at 68 (testimony of Hon. Martin R. Hoffmann, General Counsel, Department of Defense); id. at 202-03 (testimony of Cadet Captain Stephen Townes).

151. For example, military standards and strength do not appear to have suffered from the lowering of restrictions on women's flight and sea-going occupational choices, see J. HoLM, supra note 35, at 320-22, 333-34, 336-37 (describing the successful completion of standard pilot training by the first women permitted to undertake such training in the Air Force, the Coast Guard's success with mixed crews, and Naval studies and commanders' reports showing positive results from women's integration into Naval crews).

152. Griggs v. Duke Power Co., 401 U.S. 424, 436 (1971).

153. See Women Personnel Hearings, supra, note 4, at 70 (discriminatory restrictions on female personnel "unnecessarily exclude[] [military women] from high-technology, support and aircraft crew jobs, no matter how capable they are of doing those jobs") (statement of Martin Ferber, Senior Associate Director, National Security and International Affairs Division, U.S.G.A.O.). 
Thus, applying Title VII would be a significant step towards instilling within the military the values and guarantees of equal treatment that are proinoted in civilian society. The benefits would extend beyond the military, as woinen would gain new opportunities for training, education, and employment. In addition, both the military and society at large would further evolve toward full recognition of woinen's abilities to define their own life roles. Equality within the nilitary would give woinen greater involvement and responsibility both within and outside the military, in war and in peace. 
